\title{
UTILIZING RIGHTS AND WRONGS: RIGHT-WING, THE “RIGHT" LANGUAGE, AND HUMAN RIGHTS IN THE GAZA DISENGAGEMENT
}

\author{
ERAN SHOR \\ State University of New York at Stony Brook
}

\begin{abstract}
This article examines the discourses of Israeli right-wing figures who opposed Israel's disengagement from the Gaza Strip in August 2005. Relying on a systematic analysis of prominent conservative Israeli outlets, the author demonstrates an attempt to reconcile two opposing discourses: a particularistic-Jewish morality discourse and a universal rhetoric of human rights. The author shows that the use of the latter is a relatively novel phenomenon, which was absent during the struggle against Israel's retreat from the Sinai Peninsula in April 1982. Drawing on these findings and on larger global tendencies, the author offers that during the last few decades, human rights rhetoric has become politically instrumental, maybe even unavoidable, for groups and individuals who traditionally have not used it.

Keywords: human rights; right-wing; discourse analysis; Israel; occupied territories
\end{abstract}

\begin{abstract}
Some argue that political decisions must be changed in the parliament and government. Tell this to the masses that brought down the wall in Berlin, generated the Velvet Revolution in Prague, expelled Milosevic from Belgrade, dismissed Shevardnadze in Tbilisi and brought democracy to Kiev. . . . [W] hat happens when the majority crashes human rights? The United States lauds today the massive law violations during the struggle against slavery and racial segregation, because even democratic majorities may not commit crimes against humanity. The dedication of Martin Luther King and his people paid off when the general public came to recognize that they were right. . . . A regime which violates basic rights is not democratic anymore. A policy of destroying 1700 houses in Israel and exiling their residents is a crime against man and citizen, which no democracy has ever committed. (Haetzni 2005)
\end{abstract}

This monologue was written by Elyakim Haetzni, a former Israeli Member of Parliament, a settler, and a leading figure in Israeli political right. It demonstrates a

Address correspondence to: Eran Shor, Department of Sociology, Social and Behavioral Sciences Building, State University of New York at Stony Brook, Stony Brook, NY 11794; e-mail: eshor@ic.sunysb.edu.

Sociological Perspectives, Vol. 51, Issue 4, pp. 803-826, ISSN 0731-1214, electronic ISSN 1533-8673. (C) 2008 by Pacific Sociological Association. All rights reserved. Please direct all requests for permission to photocopy or reproduce article content through the University of California Press's Rights and Permissions website, at http://www.ucpressjournals.com/reprintinfo.asp. DOI: 10.1525/sop.2008.51.4.803. 
relatively new phenomenon: the utilization of universal human rights rhetoric by Israel's political right spokespeople. This utilization became remarkably prevalent during the months preceding the Israeli pullout from the Gaza Strip, in August 2005. The pullout, titled the disengagement by its initiator, former Prime Minister Ariel Sharon, stirred massive waves of resistance in Israeli right.

In this article, I examine publications by leading conservative writers that appeared in prominent right-wing Internet Web sites during the months before the Gaza disengagement. I compare these to the discourse that preceded the very similar pullout of Israeli settlements from the Sinai Peninsula, in April 1982. In both cases, the opposition to the move used instrumental (security, political, and economic) arguments, as well as particularistic Jewish moral reasoning (emphasizing Jewish entitlement and uniqueness). However, only in the latter case, the Gaza pullout, did nationalist spokespeople use the universal language of human rights. Employing this rhetoric, they spoke of human, rather than just Jewish, moral values and compared the disengagement to other struggles that have won recognition as fights against human wrongs.

Drawing on these findings and on sociological neo-institutional approaches, I argue that during the last decades human rights discourse has gained tremendous prominence in the emerging global landscape. Consequently, groups and individuals who formerly did not use a humanist rhetoric (most markedly conservative groups) now avidly employ it, recognizing that it provides an aura of moral dignity, political capital, and legitimacy. While neo-institutional arguments concentrate on universalistic human rights language as the property of progressive left-wing social movements, I will show that this discourse has become an available strategic resource, which may be employed by various political actors pursuing diverse goals.

The article begins by presenting the current global spread of universal human rights discourse and norms, along with a discussion of the most prominent theoretical explanations for their dissemination. A short review of the Gaza disengagement and Israeli political right landscape follows. Next, I introduce briefly the Israeli pullout from the Sinai Peninsula, in 1982, and the discourses of rightwing opposition that preceded it. I then compare the language used during this early withdrawal to the discourses of the opposition to the current Gaza disengagement and highlight the emerging universal human rights discourse. Finally, I situate the Israeli case in a wider global context and examine the increasing use of the universal human rights and victimization language by various groups and individuals who actually wish to promote a more particularistic and often chauvinistic or racist agendas.

\section{Theoretical Approaches to the Proliferation of "The Human Rights Regime"}

The reemergence of human rights discourse in the past decades is one of the central elements of globalization (Held et al. 1999). Following the end of the Cold War, in 1989, universal human rights have, more than ever before, come to stand in front stage, in what Donnelly (1999:71) calls "the global human rights regime." Within a few years, international attention to human rights violations 
dramatically increased (Berman 1995; Levy and Sznaider 2004), and actual violations seemed to decline (Clark 2001; Hafner-Burton and Tsutsui 2005; Risse, Ropp, and Sikkink 1999).

Constructivist scholars of international relations offer one explanation for the global proliferation of human rights in recent years and for the adoption of universal human rights norms by domestic governments. According to these scholars, states, like people, seek acceptance and legitimacy. They comply with universal human rights norms in order to ward off processes of international shaming and denunciation. Moreover, constructivists contend, human rights norms gain strength primarily due to intrinsic universalistic qualities shared by many cultures around the world that resonate with basic principles of human dignity (Finnemore 1996; Keck and Sikkink 1998). Governments may first initiate human rights improvements merely as instrumental tactical concessions, aimed at relieving pressures from the international community. However, once this language of universal human rights is used and changes are in motion, the universal moral force of the rights becomes binding and human rights violations further decrease (Risse et al. 1999).

A somewhat similar approach is offered by sociological neo-institutionalist scholars. Neo-institutionalism, originally developed in organizational studies, suggests that organizations tend to adopt elements that their environment considers to be legitimate. They often copy these elements from other organizations, thus promoting organizational isomorphism and convergence (DiMaggio and Powell 1983; Meyer and Rowan 1977). Like constructivists, neo-institutionalists emphasize the importance of norm compliance as a way to acquire legitimacy. Unlike the former, however, they do not explain the rise of humanitarian norms with reference to their intrinsic moral superiority. Norms may be adopted simply in an effort to acquire legitimacy. Since the late 1970s, neo-institutionalism has been applied to various social domains. One of its more influential extensions, the world society approach, has studied international politics, trying to explain processes such as the isomorphism of states political and social structures (Meyer, Nagel, and Snyder 1993; Meyer et al. 1997; Schofer and Meyer 2005) and states' ratification and compliance with human rights international treaties (Cole 2005; Hafner-Burton and Tsutsui 2005).

Constructivist and neo-institutional approaches are extremely valuable for understanding the adoption of universal human rights rhetoric and the patterns of struggle employed by various social movements. However, both approaches have so far focused mainly on cases in which the global human rights discourse is used by progressive social movements, campaigns that aim at influencing the state and its institutions (i.e., governments, courts, and armed forces) to comply with international norms (e.g., Hafner-Burton and Tsutsui 2005; Lutz and Sikkink 2000; Risse et al. 1999). In this article, I look at the discourse of conservative nonstate actors-political right groups and individuals-who are often characterized as violators of human rights principles. I argue that today more than ever, conservative forces recognize the elevated legitimacy that comes with the use of humanitarian language and utilize this language to their advantage. Thus, as Donnelly (1989) and Forsythe (2000) have already suggested, human rights discourse is not 
the sole property of progressive social movements. Rather, it is increasingly, at times cynically, co-opted by leaders and movements that also promote oppressive policies.

\section{The Israeli Occupation and the Gaza Disengagement}

On June 5, 1967, Israel and its Arab neighbors launched a short but highly influential war. During the next six days, the Israeli army conquered the West Bank and the Gaza Strip - two areas that are mainly populated by Palestinians. When the war ended, Israel instituted a military occupation in these territories, and citing security needs began an extensive expropriation of Palestinian lands. In fact, many of these lands were then reallocated to Jewish settlers or were taken by settlers with support from the Israeli army, government, and courts. The consistent prioritization of the Jewish settlers and their needs generated extensive violations of Palestinian rights (Lein 2002; Zertal and Eldar 2004). In December 1987, the Palestinians in the Occupied Territories launched a collective uprising against the occupation. In response, Israel increased its repressive policies. The massive expropriation of lands continued, while other violations became more frequent and severe (Btselem Report 1999). The Oslo Accords of 1993 brought a temporary subsidence of violence that was abruptly shattered in October 2000 with the onset of the second Palestinian uprising. Between October 2000 and June 2005, 3,200 Palestinians were killed by Israelis, and thousands more were wounded. During the same period, Palestinian terror acts killed almost one thousand Israelis, most of them civilians (B'tselem Report 2005b).

In late 2003, Israeli Prime Minister Ariel Sharon initiated a plan for the unilateral "disengagement" of Israeli forces from the Gaza Strip and the removal of all Israeli settlements there (a total of about 8,000 settlers). On August 15, 2005, following almost two years of votes and debates, the disengagement was carried out. Apocalyptic threats that withdrawal would cause a civil war, with many killed or wounded, turned out to be unfounded. Although some of the settlers resolvedly opposed the removal and some even resorted to mild violence, overall the eviction went smoothly. Army and police forces showed remarkable restraint in carrying out the eviction, and the whole operation was completed within nine days.

\section{Israeli Right Wing}

A radical right has existed in Israeli politics from early on, including the period before independence. Following the establishment of Israel, in 1948, the main political conflict was between those whom Sprinzak (1998) calls Maximalists and Minimalists over the borders of the Jewish state. The war of 1967, however, dramatically intensified the political divide, as religious and messianic ideas became pivotal in the politics of the Maximalists. Two Israeli religious schools have been especially prominent within this emerging messianic strain: Gush Emunim and Kach (Sprinzak 1991).

Gush Emunim, officially established in 1974, is the most vital component of Israeli radical right. Following the ideology of the Rabbis Kook (father and son), 
members of Gush Emunim hold a positive view of Zionism and see the Israeli state as an essential stage in the process of Jewish redemption. While adhering strictly to orthodox Jewish law (Halakha), they mostly desire to fully participate in the building of modern Israel. The movement became the political spearhead of the entire settlement enterprise in Gaza and the West Bank, although it has never organized as a political party (Lustick 1988; Sprinzak 1991).

Kach was established in 1971 by an American immigrant, the late Rabbi Meir Kahane. Like the leaders of Gush Emunim, Kahane believed that the Israeli victory in 1967 signified the beginning of the messianic era. However, while the theology of Gush Emunim did not originally call for violence, members of Kach have engaged in contention, violence, and street hooliganism since its establishment. Kahanes doctrine is a blend of Jewish Social Darwinism and "quasi fascist" penchant for violence against the Gentiles, Arabs in particular (Sprinzak 1999). Some of his followers have even gone to further extremes.

Other prominent radical right groups and individuals are those Sprinzak (1991) names "cultural radicals": groups and individuals who are as radical as Kahane but, rather than joining his politics, focus on bringing a cultural revolution to the nation. Although they are few, these cultural radicals play an important role in the collective consciousness of the radical right. Finally, there are those who follow the ultranationalist tradition of poet Uri Zvi Greenberg and Ze'ev Jabotinsky's revisionism. These followers are mostly secular, and they bear significant influence on Israeli parliamentary politics.

The spectrum of groups mentioned earlier is quite wide, and support for some of their agendas is extensive among the Israeli public (Sprinzak 1998). Since the common term radical right seems inappropriate to this agglomeration of groups, I will henceforth use more generic terms. These generic terms, nevertheless, must not prevent us from observing the differences among these various groups. In this article, I reviewed outlets that bring mainly (although not solely) the relatively moderate voices of Gush Emunim and its supporters, along with those of more secular ultranationalist writers.

\section{METHODOLOGY}

The study compares two historical events, Israel's pullout from the Sinai Peninsula in 1982 and the current 2005 Gaza disengagement. I begin by looking at the discourse before the Sinai Peninsula pullout, relying on secondary sources and on a sample of thirty-four articles from the settlers' most prominent outlet at the time, the monthly periodical Nekuda, between April 1981 and April 1982. The remainder of the study examines op ed articles written by right-wing publicists who argued against Israel's pullout from Gaza in August 2005. The sample for the analysis of the Gaza pullout includes all the articles that appeared in two prominent right-wing Internet Web sites-Makor Rishon (Hebrew for "Primal Source"; www.makorrishon.net) and INN (Israeli National News; www.inn.co.il)— between January 2005 and August 2005. Makor Rishon is a weekly "national Israeli newspaper." It publishes identical paper and online editions and mostly retains a moderate conservative approach. INN is an independent news Web site, 
published in both Hebrew and English, and updated daily. It mainly represents the views of more extreme ultranationalist figures. Both Web sites were thoroughly searched for articles that included arguments against disengagement. In total, 138 articles ( 94 from INN and 44 from Makor Rishon) by 35 writers were analyzed. The writers who posted articles on the two Web sites are mostly wellknown nationalist figures; they include university professors, lawyers, former high-ranked army officers, Parliament Members, and Rabbis. Some of them write in mainstream newspapers as well, and others appear as commentators on Israeli radio and television. Therefore, the arguments made in these articles were available (although to a lesser extent) to the general Israeli public as well as to the readers of the two Web sites.

The data were gathered and analyzed according to the constant comparative method for systematic qualitative content analysis (Lincoln and Guba 1985). This method integrates the introduction of the data with its interpretation, in what Maykut and Morehouse (1994) term interpretive-descriptive research. Accordingly, I use a hermeneutic approach, emphasizing the meanings people give to reality, and try to mediate between the reader and the text.

\section{2: THE REMOVAL OF SETTLEMENTS FROM THE SINAI PENINSULA}

The Gaza disengagement was not the first time in Israeli history in which the state dismantled settlements. In March 1979, the Israeli government signed a peace treaty with Egypt. The treaty contained a clause stipulating the return of the entire Sinai Peninsula, occupied since 1967, to Egypt and the removal of all Jewish settlements there. By April 1982, the last Israeli settlers were forced to leave the peninsula (Cohen 1987a). According to Truan (2005), who studied historical precedents for the Israeli pullout from Gaza, the removal from Sinai is the only historical instance of land evacuation in which citizens were (1) forced to evacuate by (2) their own democratic state, while (3) retaining their civil status. In all other historical precedents of land evacuation, one or more of these conditions were not fulfilled. Moreover, in both the Gaza disengagement and the Sinai pullout, the leading players from both sides were almost identical: from one side, a government led by the nationalist Likud party, with Sharon in a pivotal position (Minister of Defense overseeing the withdrawal in 1982; Prime Minister in 2005) and from the other side, an opposition that was led mainly by the settlers leadership of Gush Emunim.

During the months before the removal of the settlements in Sinai, domestic opposition to the Israeli retreat grew stronger. Wolfsfeld (1984) identifies three main political protest groups that formed around the retreat from Sinai: farmers, businesspersons, and the Movement to Stop the Withdrawal in Sinai (MSW). The first two groups emerged from within the Sinai settlements; both focused on the economic aspects of the withdrawal, trying to ensure that they were granted maximum compensation for evacuation and resettlement. According to Cohen (1987b), the settlers resented the need to evacuate Sinai but also acknowledged the legitimacy of the move. 
The third group, and by far the largest, the MSW, was very different in both constitution and outlook. The movement's members came almost exclusively from outside Sinai and were an ad hoc national-ideological coalition between religious Jews, who believed that Sinai was an inseparable part of the historical Holy Land of Israel, and secular Israelis, who opposed the retreat mainly for security reasons. The vast majority of MSW supporters were members of Gush Emunim, the messianic religious-national movement, which by then already had many settlements in the West Bank and a rich experience in collective action (Wolfsfeld 1984).

While most of the MSW members were primarily motivated by a religious agenda, the movement had to contend with arguments that its actions would sabotage the peace process. Therefore, much of its rhetoric focused on geopolitical and military issues, arguing that a retreat would threaten national security and ultimately lead to a bloodier war. The movement presented itself as the true and legitimate representative of Zionism, the sole defender of Israeli general interests. The holding of Sinai was portrayed as the only way to preserve collective Israeli values such as pioneering and idealism (Aran and Feige 1987; Lustick 1988).

The MSW also employed a religious-messianic rhetoric. The Sinai Peninsula was presented as a vital and inseparable part of the Promised Land of Israel, a territory which must remain under Jewish sovereignty (Cohen 1987a). Every aspect of the struggle was portrayed through a discourse of sanctity: The territory became a holy land, the settlers a holy public, the struggle was for a holy purpose, and the MSW a holy movement (Sprinzak 1991). However, the MSW made sure that its language was not limited to religious imagery; it combined religious, national, and instrumental rhetoric in its efforts to recruit public support (Kimmerling 1987).

Yet the language employed by the MSW rarely included references to universal human rights, a component that, as I will show below, was a substantial linguistic element in the fight against the more recent retreat from Gaza. In 1987, The Journal of Applied Behavioral Sciences devoted an entire issue to the retreat from Sinai, including articles analyzing the discourse of the settlers and the MSW. Other scholars (e.g., Lustick 1988; Sprinzak 1991, 1999) devoted sections of their books to the MSW and its struggle. Nowhere in these studies is there even a reference to human rights rhetoric or, for that matter, any other universal rhetoric.

A similar picture emerges when looking at issues of the settler's monthly periodical Nekuda during the twelve months before the Sinai pullout. Out of thirtyfour articles devoted to the coming move, none mentioned human rights. Table 1 shows the main themes appearing in these articles. First, many writers brought up religious and moral arguments, claiming that the peninsula is an inseparable part of the promised Holy Land of Israel. They scolded settlers who agreed to receive compensations for the move, portraying them as greedy, weak, and "surrendering to state bribery." Some articles claimed that most Israelis object to the pullout, which is therefore not democratic. And there were also those who saw the retreat as a political mistake ("a political trap"), which is bound to have severe repercussions for Israel's security.

The main slogan for the campaign against the retreat was "Do not uproot that which has been planted" (Al na ta'akor natu'a). This slogan appeared in many of the 
TABLE 1

The Discourses of the Opposition to Israeli Withdrawals: A Comparison of the Discourses before the 1982 Sinai Pullout and before the 2005 Gaza Pullout ${ }^{a}$

\begin{tabular}{|c|c|c|c|c|}
\hline \multirow[b]{2}{*}{ Type of Discourse } & \multicolumn{2}{|c|}{$\begin{array}{l}\text { Before the Sinai Pullout } \\
\text { (April } 1981 \text { to March 1982) }^{\text {b }}\end{array}$} & \multicolumn{2}{|c|}{$\begin{array}{c}\text { Before the Gaza Pullout } \\
\text { (January } 2005 \text { to August } \\
\text { 2005)c }\end{array}$} \\
\hline & $\begin{array}{l}\% \text { of Articles } \\
\text { in which } \\
\text { Discourse } \\
\text { Was Used }\end{array}$ & $\begin{array}{l}\% \text { of Articles } \\
\text { in which } \\
\text { Discourse } \\
\text { Was Not Used }\end{array}$ & $\begin{array}{l}\% \text { of Articles } \\
\text { in which } \\
\text { Discourse } \\
\text { Was Used }\end{array}$ & $\begin{array}{l}\% \text { of Articles } \\
\text { in which } \\
\text { Discourse } \\
\text { Was Not Used }\end{array}$ \\
\hline Instrumental discourses & 47 & 53 & 53 & 47 \\
\hline Security arguments & 29 & 71 & 29 & 71 \\
\hline Political arguments & 35 & 65 & 49 & 51 \\
\hline Economic arguments & 0 & 100 & 9 & 91 \\
\hline Moral discourses & 62 & 42 & 80 & 20 \\
\hline $\begin{array}{l}\text { Particular nationalist } \\
\text { or religious arguments }\end{array}$ & 62 & 38 & 30 & 70 \\
\hline $\begin{array}{l}\text { Universal human rights } \\
\text { arguments }\end{array}$ & 0 & 100 & 56 & 44 \\
\hline $\begin{array}{l}\text { Holocaust comparisons } \\
\text { and references }\end{array}$ & 0 & 100 & 22 & 78 \\
\hline $\begin{array}{l}\text { Ethnic cleansing, transfer, } \\
\text { and apartheid terminology }\end{array}$ & 0 & 100 & 15 & 85 \\
\hline
\end{tabular}

${ }^{a}$ Note that there is an overlap: Many articles contain more than one type of argumentation. Therefore, the cumulative percent for the different columns exceeds 100.

bSource: Nekuda monthly periodical, April 1981 to March 1982; N=34.

'Source: Makor Rishon weekly periodical and Israeli National News (INN) Web site, January through August $2005 ;$ N = 138.

Nekuda articles, including the headline of the front page of the December 1981 issue. It is taken from a popular song by nationalist song writer Naomi Shemer. The cry seems to be directed simultaneously to Israeli public and policy makers and to the Hebrew God (the song in its entirety is a prayer to God). Like most of the campaign, this slogan sought to emphasize the connection of the settlers to the land, the instrumental damages of the move, and the hope that God will eventually stop the retreat.

In sum, while religious, national, and instrumental rhetoric was often used to admonish against the pullout, there was almost no reference to human rights discourse. The only human right that was mentioned by the Sinai settlers was the right of possession, but it was never a major part of the settlers' rhetoric (Truan 2005). While today's settlers perceive universal rights rhetoric as indispensable, only two decades ago it hardly figured as part of the rhetorical frame.

\section{5: THE GAZA DISENGAGEMENT}

The opposition to the Gaza disengagement used two main types of arguments: instrumental and moral. Arguments of the first type emphasize the undesired consequences of the move, while arguments of the second type focus on the issues 
of justice and morality (comprising either particular or universal ethics). It should be noted, however, that the same publicists often conjoined different discourses in their writings, creating a combination of instrumental and moral arguments (for the full distribution of arguments see Table 1).

\section{Instrumental Discourses: Security, Political, and Economic Arguments}

More than half of the articles written by the disengagement opponents employed instrumental discourses, admonishing against the potential damage of the move. The writers charged that disengagement would produce disastrous results for the Israeli state and its citizens in three main areas: the security of its citizens, its international political stance, and its economy. The logic was very similar to the one used by the opposition to the 1982 Sinai pullout.

First, many of the writers argued ardently that a withdrawal from Gaza would have fatal consequences for Israeli security. According to this line of argumentation, the withdrawal would only convince the Palestinians that terrorism works and would be used to force Israel to make further concessions. That conviction, in turn, would serve as a tail wind for terror, aimed at pushing Israel out of other territories-the West Bank, or even the entire land of Israel. Thus, the Gaza Strip would become "a second Lebanon, threatening the south of Israel with technologically sophisticated missiles" (Brod 2005). Some writers also charged that the retreat would have devastative effects for the Israeli army. According to this view, the Israeli army was created to protect Jews and therefore must not deport Jews from their homes. Moshe Leshem, a former colonel in the Israeli army, wrote:

One of the major dangers brought by Sharon's disengagement plan is a mortal hit to the IDF [the Israeli army]. . . The purpose of the IDF is to . . . defend the dignity of all people, regardless of their ethnicity, religion, nationality or gender. How can these values be settled with an ethnic cleansing of Jews? . . . An army that was rightfully proud of its morality now hides its face in shame. ... An army that erases all moral and humanitarian values of justice can no longer serve as a loadstone for highly motivated national youth. ... How can the values of human dignity and liberty exclude Jews? Are the settlers of the Gaza Strip not humans? (Leshem 2005)

This highly charged text manifests a repeated duality in the writings of conservative publicists: an attempt to reconcile universal humanistic values and particular claims of Jewish privilege. I expand on this tension later.

About half of the political right writers emphasized political dangers in their opposition to the disengagement. Generally, such arguments focused on problems linked to the political decision to withdraw and the political problems that would likely ensue. First, many severely criticized what they saw as a nondemocratic move on the part of Sharon and his government in refusing to subject the plan to a general referendum. Dr. Yehuda Tzoref (2005a) concluded that since the disengagement plan "has never received a real democratic ratification ... the government lost its right to lead the country, to determine policies and to legislate laws." 
Right-wing publicists were also convinced that the disengagement would have disastrous strategic implications for the status of the Israeli state and for Zionism. They saw the pullout not only as wrong in itself but also as a dangerous precedent, bound to intensify political pressures on Israel to retreat from further territories. War strategy expert Yosef Doriel contended that the retreat "convinces the International community that Israel admits the illegality of Jewish settlements beyond the Green Line, and starts repairing the 'grievance'.... This would lead to a 'natural' demand to continue 'repairing the grievance' in the West Bank" (Doriel 2005). Some writers saw the retreat as jeopardizing not only Israel's control of the occupied territories but rather the whole Zionist enterprise and the Jewish state. Law expert Dr. Haim Misgav wrote:

If the status of the Gaza settlements is temporal, what prevents us from seeing [the Israeli cities] Ashdod, Ashkelon, Ramla, Lydda, Beer-Sheva, Eilat or Karmiel as occupied territories, which would have to be evacuated eventually? ... Judicially, there is no difference between the occupations of 1948 and those of 1967. (Misgav 2005)

An even gloomier affirmation regarding the repercussions of the retreat came from Dr. Yehuda Tzoref (2005a): "An ethnic cleansing of Jews in their homeland gives a post-factum moral legitimization to the crimes carried out against the Diaspora Jews because of their nationality." In Tzoref's rhetoric, it is not only the state of Israel that stands in danger in face of the Gaza evacuation but rather the whole existence of the Jewish people.

Finally, a less common, but still salient line of reasoning referred to the economic costs of the move, which some believed would jeopardize Israeli economy. Michael Fuah (2005a), a prominent political activist, wrote:

Why should we devote tens of millions to building detention camps for the settlers with no public discussion or scrutiny, instead of devoting this money to developing the Israeli south? . . . And how would all this be funded? From monies devoted to public health, infrastructures, education and more. ... Has anyone considered offering money to the Arabs of Gaza so they would willingly leave the strip? ... This alternative is, undoubtedly, morally and economically superior.

In conclusion, the instrumental line of reasoning emphasizes security, political, and economic aspects. Contentions of this sort are not new; they were a major part of the struggle prior to the Sinai pullout. However, these "rational" arguments were clearly not deemed sufficient in this instance, and claims of morality and rights were also widely mobilized.

\section{Moral Discourses: Particularism and Universalism}

Discourses of morality and rights violation were especially prominent among ultranationalist publicists. Two main strains ruled this discourse: a particularistic Jewish rights strain and a universal morality one. At times, the two appeared separately, but for the most part they were combined, forming an interlaced discourse of particularistic/universal morality. 


\section{"A Jew Does Not Expel Another Jew": Particular Jewish Morality and Rights}

About 30 percent of the writers bolstered their rejection of the move with arguments of Jewish particularism. Most of them referred to the divine and natural entitlement of the Jewish people to the entire Land of Israel, which no secular source of authority (i.e., government, parliament, or court) may waive. Professor Hillel Weis of Bar-Ilan University wrote:

The [Jewish state's] source of authority is not the parliament, the rule of law, or the Israeli government, but the Eternal of Israel [the Hebrew God]. Only as long as the Israeli parliament and its institutions represent the Eternal of Israel, or at least pretend to represent it, are they legitimate... . The source of authority lies in the deep acknowledgement and consent of the Jewish people that the Land of Israel is its historical homeland, given to it by God in order to possess it and sit in it. (Makor Rishon, April 1, 2005)

Some writers further maintained that the Jewish people are unique and morally superior. They contended that the disengagement, or the deportation/uprooting as they called it, contradicts the unique values of Jewish morality and conscience. Professor Weis charged that "[we] refuse to participate in the act of uprooting, and to obey the anti-Zionists and anti-Jewish commands" (Makor Rishon, April 1, 2005). Dr. Yehuda Tzoref (2005c) displayed similar views:

Israel is the only place in the world today devising ethnic crimes against Jews. . . I It is the most anti-Semitic political entity in the world. The state of Israel gradually loses its democratic, moral and Jewish character, becoming a predatory apparatus, threatening all Jews. ... Israel symbolizes today the pure antithesis to the universal destination of the Jewish people. Therefore, every moral Jewish man must renounce himself from this brutal state apparatus. The bitter destiny of the Israeli state illustrates the inevitable failure of any sovereign Jewish statehood, which does not rely upon the ancient moral rules of Jewish existence.

In another article, Tzoref (2005b) argued that Jewish people must follow not only a unique destiny but also superior morality:

The struggle for the revival of Israel is the cleanest, purest and most moral national struggle since the dawn of human history. . . . Every man of conscience, Jewish or Gentile, must support the return of the Jewish people to their biblical Promised Land.

These perceptions are in line with an old (self) view of Jews as the chosen people. The choice bestows Jews with unique rights and destinations but also involves moral and religious commitments, superior to those of the gentiles. Jews must serve as "a light to all nations" and provide other peoples with moral guidance and inspiration. This is the "universal destination of the Jewish people" about which Tzoref talks. The nature of Jewish particularism is thus essentially universal. Jews are committed to the fate of humanity and therefore are obliged to always act morally without mutual expectations from the Gentiles. According to Luz (2002), this is how great scholars of the Hebrew Talmud saw this commitment. 
However, influential Israeli ultranationalist figures, such as Rabbi Meir Kahane, developed a counteruniversal concept of "Jewish ethics." According to this new perception, universal morality is a secular Western concept, alien to the Torah. Jews are commanded to be "holy," rather than to comply with the false "moral" standards of the gentiles; Jewish ethics has no room for "excessive righteousness."

The perception of the disengagement as a blow to unique Jewish morality was also expressed in the leading slogan of the opposing settlers: "A Jew does not expel another Jew" (Yehudi lo megaresh Yehudi). During the months before the disengagement, this motto appeared on stickers, on signs in demonstrations, and even in popular radio songs. It summarizes the essence of the right perceptions-a few words that convey an opulence of meanings. First, there is the active person, the one who is about to perform the act of expulsion. How, the opponents ask, can a "morally superior" Jew take an active role in a violent and inhumane act of dispossession? However, this is not a general moral cry "A Jew does not expel" but rather the narrow "A Jew does not expel another Jew."

The term expel was also carefully chosen. Jewish history is perceived and constructed as a series of grievances and injustices. The term expulsion enfolds a gamut of symbolic meanings and associations in Jewish consciousness. The history of the Jewish people is paved with expulsions, from the first and second temple exiles at the start of the first millennium, through the Spanish expulsion of Jews in 1492, and up to various expulsions of Jews in modern Europe. In Jewish ethos, the Israeli state embodies a rightful and just return to the lands from which Jews were banished, a compensation for the wrongs of two millenniums. The price paid by Palestinians to enable this compensation is conceived, at best, as necessary and reasonable, a lesser evil. Many articles in the present study reflect this view, associating the current disengagement with iniquities from Jewish history. These include mainly expulsions but also infamous pogroms and even the Jewish Holocaust, which I discuss later.

\section{"Carrying the Flags of Human Rights, Freedom and Morality": The Universal Discourse}

Alongside the traditional particular Jewish discourse, a new, somewhat surprising, discourse of universal morality and human rights has emerged in the writings of right-wing publicists. Over half of the articles examined mentioned universal human rights violations as a reason to object to the disengagement. In about 30 percent of the articles, this element was central to the piece.

Human rights language is not alien to participants in the Israeli-Palestinian conflict. For years, the Palestinians, domestic and international human rights organizations, and the Israeli left wing have been denouncing Israel's severe violations of Palestinian rights. The Jewish settlers contribute considerably to these violations. Not only are they systematically prioritized by the Israeli government, army, and legal system (Zertal and Eldar 2004), but they have also engaged in the violent prevention of agricultural harvests, physical injuries, and even killings of Palestinians (B'tselem Report 2005a). However, with the introduction of the disengagement plan, conservative writers described settlers as victims, "raped" by the state, the army, and everyone in the Israeli public who supported the move. 
Uri Elitzur (2005), who served as the office director of former Prime Minister Binyamin Netanyahu in the late 1990s, wrote:

This is the stage of dehumanization. Slowly pushing out the victim, secluding him, while at the same time creating the protective-group feeling for the perpetrators. . . Some of the settlers will respond violently; it is only natural and humane. Why assume that we are different from other humans? The sheep may scratch the wolf just before it is swallowed. . . . Do not cooperate with those who try to turn citizens into monkeys and people into bugs you can crash; this is a boomerang. Today you are the ones who crash, but tomorrow you will find yourselves under the shoe.

Following years of disregard and dismissal of the charges by Palestinians and ("the bleeding-heart") human rights advocates, political right figures have now ardently adopted the universal rights discourse. Withdrawal, they charged, would be an uprooting that impinges on human dignity, injures freedom of speech and freedom of movement, violates rights to property and freedom of occupation, and results in the extralegal administrative arrests of protesters. They denounced the "debasement of universal human rights in order to make room for non-democratic, strange, and outlandish values" (Breiman 2005) and wondered what happened to all those nongovernmental organizations (NGOs) and left-wing activists who fought so fervently for the rights of the Palestinians but failed to protest the infringements of settlers' human rights. The Israeli Supreme Court was also condemned for not stopping the move. The settler Boaz Haetzni wrote:

Only lunatics believe that the Israeli Supreme Court would be impressed by the laws of human dignity and freedom, and by the rights of possession of 9,000 settlers, although the same court prevented the deportation of a few family members of terrorists from the West Bank to Gaza. . . . The "disengagement" has become a touchstone for the leading elements in Israeli society. . . . Those who fight against it carry simultaneously the flags of human rights, freedom and morality. (Makor Rishon, March 18, 2005)

Interestingly, conservative publicists often adopted, almost word for word, the discourse of universal human rights used by human rights NGOs and Israeli political left. Attacks on army roadblocks were a prominent example of this adopted linguistic repertoire. From the beginning of the first Palestinian uprising, the Israeli left had criticized Israel's use of roadblocks, pointing out their severe effects on the Palestinians. Left-wing activists often plead with Israeli soldiers to refuse to take part in this practice, charging that under such conditions it is impossible to preserve a human image. A few weeks before the disengagement, the Israeli army closed the Gaza Strip, preventing the passage of right-wing activists who attempted to stop the removal. Settlers were required to show a residency ID in order to enter the Strip. Political right activist Michael Fuah (2005b) harshly denounced this practice:

This is how it all began 65 years ago, when they discriminated among citizens. Not because they did anything wrong, not because they were enemies, but simply because they were Jews. ... Everything was legal. Some of the executers were even Jews themselves.... How can you [the soldiers and policemen 
of the roadblocks] remain good human beings when participating in such an awful thing? . . . It does not start with the gas chambers; it ends there. It starts with your obedience and with you shutting your eyes and hearts. ... Do not delude yourselves; you are part of a destructive apparatus. ... When one day, God willing, we enact laws of justice for the criminals of the deportation and their collaborators [Fuah alludes to the 1950 Israeli basic law of "Justice for the Nazis and their Collaborators"], you will be among the first to be trialed for your legal, but immoral, acts.

\section{Employing the Holocaust and Other Universal Straggles}

Fuah introduces a clear and unabashed comparison between the disengagement and the Jewish Holocaust. This comparison was one of the most interesting aspects of the right rhetoric. Opponents of the disengagement often associated their fight against the plan with historical infringements and human rights struggles that have gained symbolic cosmopolitan standing. The two historical cases most commonly used were the Jewish Holocaust and the fight of the Black movement for liberation and equality in the United States.

About one-fifth of the articles in the study used terms associated with the Jewish Holocaust. Some of them even presented the disengagement as a new holocaust. One could argue that since the Holocaust was a Jewish tragedy, references to it are testimony to particularistic moral claims. This is undoubtedly true to some extent, especially in Israel where many perceive the Holocaust as the sole "property" of the Jewish people-something that could happen only to Jews. However, as Samuels (2000) observes, the Holocaust and its memory today also carry a distinct universal relevance. Levy and Sznaider (2004) contend that the Holocaust, perceived as an ideal type of clear and indisputable evil, has become a cosmopolitan moral touchstone in an age of uncertainty. It has been "dislocated from space and time precisely because it can be used to dramatize any act of injustice, racism, or crime perpetrated anywhere on the planet" (p. 156). This cosmopolitan view of the Holocaust has also permeated the Israeli arena. The Palestinians, foreign human rights advocates, and even left-wing Israeli activists often associate aspects of the Israeli occupation with the Holocaust (Israeli soldiers, for example, are equated with Nazi SS and the Palestinian refugee camps with German Ghettos). This tension between the particularistic-Jewish and the cosmopolitan perception of the Holocaust was evident in the writings of those who opposed the disengagement. Dr. Benjamin Kelner (2005), a former army colonel, wrote:

[The Holocaust is] the most horrible event in the history of humanity. It is unique because it is so well documented. There have been other calamities and enormities, maybe even worse ones, but the Holocaust was minutely documented. . . . There were more holocausts, those of the Armenians, the Biafrians, the Cambodians and even the Russians under Stalin. Like the Jews, these people had no country of their own, and therefore nowhere to run to and no one to speak for them.... The delusionary "disengagement plan" calls for a new holocaust.

While Kelner is clearly worried about the Jewish people, his rhetoric refers to the universal lessons that must be learnt from the Holocaust: People (any people) 
must have a country of their own in order to prevent a new holocaust from happening.

The other historical event which the writers often referred to is the struggle of American Blacks for freedom and equality. Ultranationalist Parliament Member Professor Arieh Eldad called for a civil insurrection against the disengagement. Building on philosopher Jean Jacques Rousseau, Eldad claimed that when the state unilaterally violates its "social contract" with the citizens, the only way left is turning to nonviolent civil insurrection:

This is the exact passive protest adopted by Mahatma Gandhi in India and Martin Luther King in the United States. They deliberately violated laws which were properly legislated, but were immoral or racist, and won universal glory for their civil insurrection. [Similarly,] the laws of the disengagement are racial laws, directed at 8000 Jews. These are immoral and antidemocratic laws that impinge on the basic rights of the deported. Therefore, there is a superior moral need to break them off. (Eldad 2005)

Other writers employed similar rhetoric. Ze'ev Galilee quoted Sydney Frish, "a true leftist" who "believes in the basic rights of all humans." The American-born Frish relied on American history: "The Nigger let the White man step on him . . . until a Black priest, Martin Luther King, rose up and declared that the Blacks do not ask for rights-they demand these rights." Frish equated this to the fight for recognition of the Israeli national-religious camp: "Until now, we agreed to participate in the rules of the 'democratic game.' But now the games are over. . . W We will meet in Gush Katif [Gaza] and regroup in the style of Martin Luther King." Frish ends with a call to all Israeli (male) Jews: "Gentlemen, during the next couple of months let us all be New-Yorkers-let us properly celebrate Martin Luther King's Day" (Makor Rishon, March 4, 2005).

Apart from the comparisons to the Holocaust and to universal freedom struggles, adversaries of the disengagement also frequently referred to it using three terms that have become bywords for universal evil: ethnic cleansing, transfer, and apartheid. While ethnic cleansing is often associated with the extermination of people, it also serves to describe the use of force or intimidation to remove people of a certain ethnic or religious group from an area. ${ }^{2}$ The term apartheid is most widely associated with the racist white regime that ruled South Africa until the early 1990s. However, it is also commonly used by human rights advocates and scholars to describe the Israeli Occupation of the West Bank and Gaza (e.g., Akenson, 1992; Glaser 2003). Nationalist proponents, who used the term when referring to the disengagement, contended that for Sharon and the Israeli left, "the mere existence of Jews in the vicinity of Arabs is 'intolerable for the Palestinians.' If this is not racial and anti-Semitic apartheid, what is?" (Tzoref 2005b).

In sum, writers who objected to the Israeli withdrawal from the Gaza Strip employed a clear and extensive use of a universal rhetoric of rights, a rhetoric that was not evident during the Sinai pullout twenty-three years earlier. At the same time, the use of universal human rights discourse by right-wing publicists was mostly combined with a particular discourse that undercut its claims to universalism. 


\section{DISCUSSION}

I examined the discourse of the political right opposition to the Israeli retreat from the Gaza Strip. This discourse included instrumental arguments of security, political, and economic nature but mainly employed a rhetoric that vacillated between claims about Jewish rights and universal morality, striving for an almost impossible affixion of the two. Particularistic conceptions have always been part of Israeli nationalist tenets. Following a chauvinistic interpretation of the biblical concept "the chosen people," leading right figures have repeatedly justified their actions with the alleged moral superiority of the Jewish people and its distinct entitlements. The novelty in these arguments, however, appears in their use of universal human rights rhetoric. This framing mechanism was not part of the discourse before the 1982 Sinai pullout. Following years of disregard and even contempt for those denouncing Israeli violations of Palestinian human rights, the settlers and their supporters redeployed the rhetoric of universal human rights, charging their opponents with humanitarian insensitivity and inferior morality.

Of course, one would have to be quite naïve to take these universal human rights proclamations at face value. Even when the writers utterly believe in their own rhetoric (which, quite often, seems to be the case), the texts they produce, as well as their actual behavior, suggest that the disengagement did not cause a dramatic changeover in the particularistic morality that has ruled their reason and actions for years. The words may be adapted to the universal moral discourse of human rights, but the perceptions stay self-interested and nationalistic. "A Jew does not expel another Jew" was not replaced by "A human being does not expel another human being." What is it, then, that drives this use of universal humanistic language in the statements? How did a discourse that only two decades earlier was considered negligible or reserved for bleeding hearts become a critical part of the antidisengagement frame?

The answer lies in both domestic and global developments during the last two decades. First, we must consider the change in the perceived social and political position of the settlers vis-à-vis Israeli public and the Israeli state. In 1982, before the Sinai pullout, the settlers felt that the state was making a mistake in signing the peace treaty with Egypt and agreeing to give away the Sinai Peninsula. However, they still believed that their general views and positions were shared by the mainstream of the Israeli public and their actions supported by the Israeli state and its institutions. The settlers saw themselves as the new spearhead of state Zionist ideologies, taking the lead from the old and jaded labor movement. Their rhetoric was therefore largely embedded within the rhetoric of the state, emphasizing Jewish rights over the land and security considerations. The leading slogan during the 1982 campaign, "do not uproot that which has been planted," was very much rooted in mainstream Zionism. Its adoption symbolized the common sentiment among the settlers of being in the forefront of Zionism but as an inseparable part of Israeli society and state.

During the two decades that followed, this belief has been gradually undermined. The rift between the settlers and the state began with the signing of the Oslo Accords, in 1993, in which the Israeli government declared its intent to pursue peace with the Palestinians based on a compromise over the Occupied Territories. 
Haklai (2003), who writes about the struggle of the settlers during the years that followed the Oslo Accords, describes a feeling of being excluded from the decision-making process in the government. Moshe Feiglin, one of the more vocal opponents of the Accords, expressed in an interview the growing sentiment of alienation from the state and from mainstream Zionism: "Zionism has abandoned us. There is no more Zionism. Now we are left with ourselves, with our Lord, and with our Judaism" (Dolev 1995: 38).

By 2005, the feeling that they were abandoned by mainstream Zionism and by the Israeli state has permeated large publics within the Israeli political right. Once again, the settlers felt that they were left outside of the decision-making processes, but this time this was done by a largely nationalist government, led by the formerly idolized Ariel Sharon. Indeed, many of the writers cited in this study expressed the feeling that the state and its institutions (the government, the security forces, and the courts) have abandoned them and, for that matter, also abandoned "true Zionism." Therefore, one must not rule out the possibility that the settlers indeed felt subject to violations of their human rights and that their cry against these violations was authentic. The human rights discourse was thus, at least partly, directed toward the international community, which was expected to provide remedy where the state had failed and maybe even intervene to stop the move.

While this is a plausible explanation, the sweeping acculturation of the universal human rights discourse, which in previous years has mainly drawn the scorn of right-wing activists, is still puzzling. To understand this dramatic development we must also consider the emergence of a cosmopolitan human rights regime, in which humanitarian issues have become dominant in the global arena, and attention to human rights violations increased substantially (Donnelly 1999; Held et al. 1999). This global human rights renaissance was accompanied by marked domestic developments. The 1987 break of the first Palestinian uprising brought a significant revival in Israeli human rights activity on both the local and the international levels. In the succeeding years, existing local and international human rights organizations expanded their activities and new organizations were formed (Hajjar 2001; Hanafi and Taber 2004). Although pressures by human rights NGOs and the international community brought only moderate changes in the actual violations of Palestinian rights (Shor 2008), they did cause a gradual shift in Israeli discourse. The use of rights language in the Israeli media has significantly increased since 1987 (Gordon and Berkovitch 2007), and human rights discourse has also permeated Israeli public arena (Ben-Eliezer 2003), legal system (Benvenisti 1994; Hajjar 1997; Ziv and Shamir 2000), and local politics (Kemp and Raijman 2000).

These developments may be partly explained by a constructivist international relations approach, which emphasizes the combined role of transnational and domestic networks of humanitarian advocacy in states' adoption of international human rights norms (Finnemore 1996; Keck and Sikkink 1998; Risse et al. 1999). However, explanations offered by constructivist scholars have an important shortcoming when applied to the Israeli case. Constructivist views suggest that once the language of human rights has been adopted, actors become committed 
and the universal moral force of the rights becomes binding. In other words, once the universal rights language has been used, the normative value of these rights makes it almost impossible to renounce them. However, this does not seem to be the case for Israeli political right proponents. For them, the use of the universal discourse was largely a rhetorical tactic, and following their actions since the disengagement, it seems that the use of this discourse has not led to perceptual changes regarding the rights of non-Jews.

Neo-institutionalism and world society approaches seem to provide a better account for the processes at hand. They offer that "contemporary constructed actors . . . routinely organize and legitimize themselves in terms of universalistic (world) models ... . [that are] pervasive at the world level, with a considerable amount of consensus on the nature and value of such matters as citizen and human rights" (Meyer et al. 1997:148). The adoption of a universal humanitarian language by the Israeli political right seems to embody this contention. It was an attempt to acquire political capital by gaining moral legitimacy and public sympathy from the international community and the Israeli public, as well as influence Israeli courts to legally hinder the move. While emphasizing the isomorphic power of human rights norms, neo-institutionalists, unlike constructivists, do not suggest that these norms carry an intrinsic universal moral value. Actors often adopt the universal humanitarian discourse simply for instrumental purposes (acquiring legitimacy or placating pressures), and consequent processes of norm internalization do not necessarily occur. The settlers continued disregard for Palestinian rights since the disengagement suggests that this may be the case with the Israeli right.

That said, the Israeli case also demonstrates an important extension of both constructivist and world society approaches. Both approaches focus their arguments on the way human rights language and humanitarian norms are used by left-wing parties and NGOs that seek to influence repressive governments. In the Israeli case, however, it is conservative nationalist activists and movements who utilize this discourse in an attempt to gain public sympathy and legitimate their struggle. We must recognize, therefore, that the spread of human rights rhetoric and norms is not limited to progressive social movements. The proliferation of the human rights regime is recognized by various actors, who realize the instrumental, if not the moral, value of this regime and utilize it to gain political capital (Forsythe 2000).

The Israeli case is thus indicative of a more general strain. During the last decades, human rights rhetoric has gained such dominance and importance that it became invaluable even for actors and groups that traditionally refrained from using it. Only few today can allow total disregard for the universal human rights regime. Human rights discourse, if only as a lip-service, has become an available resource for those seeking political influence and power. It provides its users with extended legitimacy for their struggles and with an aura of respectability that no other rhetoric can supply. ${ }^{3}$ This discourse may be (and increasingly is) utilized by governments and groups, which use it as a lever for political gains, even when universal rights are actually the last thing on their agenda. 
Prominent among these are conservative and nationalistic groups, which often try to justify inhumane causes by using a universal discourse of (human) rights. As with Israel, the new populist right in Western Europe emphasizes self-interests, particularism, and nationalism but concurrently claims that it represents "the true spirit of democracy" and adopts the language of cultural rights, economic rights, victimization, and humanism. Populist right movements in France (Hainsworth 2000), Germany (Backer 2000), the Netherlands (Mudde and Van Holsteyn 2000), and Scandinavia (Svasand 1998) justify anti-immigrant policies with alleged violations of the cultural and economic rights of the indigenous people. These claims intertwine with the talk of universal rights. Thus, for example, populist right spokespeople in France justify their objection to Muslim immigrants with claims that Muslim culture supports the oppression of individual rights (Eatwell 2000).

Similar tendencies may be found in North America. Lio, Melzer, and Reese (2006) examined the discourse of the conservative English-only and gun rights movements in the United States. These movements increasingly appropriate the master frame of rights to broaden their appeal. The National Rifle Association (NRA), for example, links the defense of gun rights to the defense of freedom. The NRA contends that the right to bear arms is inseparable of all other rights and freedoms, protected by the Second Amendment, and consequently any threat to gun rights is a threat to all individual rights. Charlton Heston, who served as the president and spokesperson of the NRA between 1998 and 2003, equated the struggle against gun control to the 1960s fight for civil rights, saying that "supporting civil rights [in 1963] was about as popular as supporting gun rights is now." Other speakers commonly refer to the NRA as the biggest and oldest civil rights organization in the United States and speak of gun owners as a persecuted minority, fending off oppression. This language of victimization has largely taken over the discourse of NRA spokespeople. Despite the fact that there is no history of systematic discrimination or violence against gun owners within the United States (as there was, for example, against racial minorities), NRA leaders frame gun owners as a persecuted minority. Much like Israeli settlers, they adopt the rights language to mobilize support for their causes and fend off what they see as "the injustice of societal oppression imposed via gun control" (Lio et al. 2006:24).

Kimmel (2003), who compared the discourse of white supremacists in the United States and in Scandinavia, describes similar patterns. In the United States, these include groups such as the White Arian Resistance, the John Birch Society, the Ku Klux Klan, the American Nazi Party, and Holocaust deniers. In their interviews, members of these groups often portray themselves as victims of the new American elites and stress that their "natural rights" are being breached by immigrant groups, African Americans, Jews, women, and other minorities. White supremacy groups in Scandinavia, such as the Bootboys and the Vikings (Norway), the Green Jacket Movement (Denmark), and the Swedish Riksfronten (National Front), express very similar contentions, presenting themselves as the victims of women, homosexuals, and the "global Zionist power" and stressing the violation of their natural human and civil rights. 
Finally, the use of human rights rhetoric has also penetrated the Muslim world and, in particular, the Palestinian political right. Palestinian terrorist groups such as Hamas and the Islamic Jihad often justify terrorist acts by referring to Israeli violations of Palestinian universal human rights. These groups seek, and often find, sympathy and financial support in the Arab world and in the international community by emphasizing the breach of both individual and collective rights of Palestinians. Terms such as genocide, war crimes, crimes against humanity, ethnic cleansing, and apartheid became an integral part of the Palestinian political right rhetoric and are often used side by side with the more traditional religious and nationalistic claims (see, for example, Matas 2005). Thus, ironically, severe violations of human rights are justified with the language of rights, and humanitarian discourse is utilized for achieving political gains.

Acknowledgments: The author thanks Daniel Levy, Kiyoteru Tsutsui, Naomi Rosenthal, Michael Schwartz, David Roelfs, Alwyn Lim, Amy Braksmajer, and the editors and anonymous reviewers of Sociological Perspectives for their helpful comments and suggestions on former drafts of this article.

\section{NOTES}

1. Ironically, looking at the history of the settlers shows that democracy and formal legal procedures were never before a first priority for them. Pedatzur (1996) describes the long-lasting utilization of the Israeli democratic system by the settlers to create irreversible facts through establishing unauthorized settlements that were later legitimized by Israeli governments. As long as Sharon was on the settlers' side, supporting their bypass of democratic procedures, they considered him as "the father of the settlements," "a bulldozer," and "a man of action," who "knew how to cut corners." However, once Sharon decided to remove some of the settlements, these exact traits were used to attack him. He was portrayed as "a ruthless and ravenous dictator, a bulldozer with an uncontrolled lust to destroy, who runs over anything and anyone standing in his way."

2. Adhering to this definition, it seems like the settlers have a good case for using this term. The disengagement is indeed the removal of Jews, and Jews only, from the Gaza Strip. Nevertheless, such a narrow perspective ignores the initial occupation of the territory and the measurements taken along the years to secure the settlers' rooting in the Strip (Pedatzur 1996; Zertal and Eldar 2004).

3. To be clear, I do not suggest here that human rights function today merely as a discourse or an empty vessel, a self-referential floating signifier, which lost connection with its actual realistic base, in the words of Baudrillard. Such a proposition seems absurd when viewing the tremendous impact this discourse has on human rights violations and the overwhelming improvements it has brought to the lives of so many.

\section{REFERENCES}

Akenson, Donald H. 1992. God's Peoples: Covenant and Land in South Africa, Israel and Ulster. Ithaca, NY and London: Cornell University Press.

Aran, Gideon and Michael Feige. 1987. "The Movement to Stop the Withdrawal in Sinai: A Sociological Perspective." The Journal of Applied Behavioral Science 23: 73-87. 
Backer, Susan. 2000. "Right-Wing Extremism in Unified Germany." In The Politics of the Extreme Right: From the Margins to the Mainstream, edited by P. Hainsworth. New York: Pinter.

Ben-Eliezer, Uri. 2003. "New Associations or New Politics? The Significance of Israeli Style Post-Materialism." Hagar, International Social Science Review 4: 5-35.

Benvenisti, Eyal. 1994. "The Influence of International Human Rights Law on the Israeli Legal System: Present and Future." Israel Law Review 28: 136-53.

Breiman, Ron. 2005. “Democracy or Sharonocracy." INN, July 25. Retrieved August 5, 2008, from http:/ / www.inn.co.il/Articles/Article.aspx/4636

B'tselem Report. 1999. "Oslo, Before and After: The Status of Human Rights in the Occupied Territories." Jerusalem: B'tselem, Retrieved July 27, 2005, from http:// www.btselem.org/Download/199905_Oslo_Before_and_After_Eng.doc

. 2005a. "Settler Violence." Jerusalem: B'tselem, Retrieved August 4, 2005, from http://www.btselem.org/english/Settler_violence/Index.asp

_. 2005b. "Use of Firearms." Jerusalem: B'tselem, Retrieved August 4, 2005, from http:/ /www.btselem.org/English/Firearms/

Berman, Marshall. 1995. "Modernism and Human Rights near the Millennium." Dissent 42: 333-41.

Brod, Menachem. 2005. "The Tactic Failed, Truth Will Succeed." INN, March 3. Retrieved August 5, 2008, from http:/ /www.inn.co.il/Articles/Article.aspx/4135

Clark, Ann Marie. 2001. Diplomacy of Conscience: Amnesty International and Changing Human Rights Norms. Princeton, NJ: Princeton University Press.

Cohen, Erik. 1987a. "Introduction to the Price of Peace: The Removal of the Israeli Settlements in Sinai." The Journal of Applied Behavioral Science 23: 1-11.

- 1987b. "The Removal of the Israeli Settlements in Sinai: An Ambiguous Resolution of an Existential Conflict." The Journal of Applied Behavioral Science 23: 139-49.

Cole, Wade M. 2005. "Sovereignty Relinquished? Explaining Commitment to the International Human Rights Covenants, 1966-1999." American Sociological Review 70: 472-95.

DiMaggio, Paul J. and Walter W. Powell. 1983. "The Iron Cage Revisited: Institutional Isomorphism and Collective Rationality in Organizational Fields." American Sociological Review 48: 147-60.

Dolev, Meira. 1995. "The People Is Me (I am the Original; Rabin is Fake): An Interview with Moshe Feiglin." Nekuda 188: 38-39.

Donnelly, Jack. 1989. Universal Human Rights in Theory and Practice. New York: Cornell University Press.

- 1999. "The Social Construction of International Human Rights." Pp. 71-102 in Human Rights in Global Politics, edited by T. Dunne and N. J. Wheeler. Cambridge, UK: Cambridge University Press.

Doriel, Yosef. 2005. "How Will Tomorrow Look Like?" INN, May 5. Retrieved August 5, 2008, from http://www.inn.co.il/Articles/Article.aspx/4294

Eatwell, Roger. 2000. “The Rebirth of the 'Extreme Right' in Western Europe?" Parliamentary Affairs 53: 407-25.

Eldad, Arieh. 2005. "What Is Civil Insurrection?" Retrieved July 30, 2005, from http:// www.meri.org.il/esber.html (Hebrew)

Elitzur, Uri. 2005. “The Crushing Mob." INN, February 25. Retrieved August 5, 2008, from http://www.inn.co.il/Articles/Article.aspx/4006

Finnemore, Martha. 1996. "Norms, Culture, and World Politics: Insights from Sociology's Institutionalism." International Organization 50: 325-47.

Forsythe, David P. 2000. Human Rights in International Relations. Cambridge, UK: Cambridge University Press. 
Fuah, Michael. 2005a. “The Great Financial Scam." INN, March 15. Retrieved August 5, 2008, from http://www.inn.co.il/Articles/Article.aspx/4069

—. 2005b. "I Ran Out of Questions." INN, July 24. Retrieved August 5, 2008, from http://www.inn.co.il/Articles/Article.aspx/4634

Glaser, Daryl J. 2003. "Zionism and Apartheid: A Moral Comparison." Ethnic and Racial Studies 26: 403-21.

Gordon, Neve and Nitza Berkovitch. 2007. "Human Rights Discourse in Domestic Settings: How Does It Emerge?" Political Studies 55: 243-66.

Haetzni, Elyakim. 2005. "Yesha, a Self-Eating Body." INN, April 14. Retrieved August 5, 2008, from http://www.inn.co.il/Articles/Article.aspx/4209

Hafner-Burton, Emilie M. and Kiyoteru Tsutsui. 2005. "Human Rights in a Globalizing World: The Paradox of Empty Promises." American Journal of Sociology 110: 1373-411.

Hainsworth, Paul. 2000. "The Front National: From Ascendancy to Fragmentation on the French Extreme Right." Pp. 18-31 in The Politics of the Extreme Right: From the Margins to the Mainstream, edited by P. Hainsworth. London and New York: Pinter.

Hajjar, Lisa. 1997. "Cause Lawyering in Transnational Perspective: National Conflict and Human Rights in Israel/Palestine." Law and Society Review 31: 473-504.

. 2001. "Human Rights in Israel/Palestine: The History and Politics of a Movement." Journal of Palestine Studies 30: 21-38.

Haklai, Oded. 2003. "Linking Ideas and Opportunities in Contentious Politics: The Israeli Nonparliamentary Opposition to the Peace Process." Canadian Journal of Political Science 36: 791-812.

Hanafi, Sari and Linda Taber. 2004. Donors, International Organizations and Local NGOs: The Emergence of Palestinian Globalized Elite. Washington, DC: Palestine Studies Institute.

Held, David, Anthony McGrew, David Goldblatt, and Jonathan Perraton. 1999. Global Transformations: Politics, Economics and Culture. Stanford, CA: Stanford University Press.

Keck, Margaret E. and Kathryn Sikkink. 1998. Activists beyond Borders: Advocacy Networks in International Politics. Ithaca, NY: Cornell University Press.

Kelner, Benjamin. 2005. "The Lesson of the Holocaust Has Not Been Learned." INN, May 16. Retrieved August 5, 2008, from http:/ / www.inn.co.il/Articles/Article.aspx/4329

Kemp, Adriana and Rivka Raijman. 2000. "Foreigners in the Jewish State: The New Politics of Migrant-Labor in Israel." Israeli Sociology 3: 79-110 (Hebrew).

Kimmel, Michael S. 2003. "Globalization and its Mal(e)contents: The Gendered Moral and Political Economy of Terrorism." International Sociology 18: 603-20.

Kimmerling, Baruch. 1987. "Exchanging Territories for Peace: A Macrosociological Approach." The Journal of Applied Behavioral Science 23: 13-33.

Lein, Yehezkel. 2002. "Land Grab: Israel's Settlement Policy in the West Bank." Jerusalem: B'tselem, Retrieved April 25, 2005, from http://www.btselem.org/Download/ 200205_Land_Grab_Eng.pdf

Leshem, Moshe. 2005. "Arik Sharon Is Destroying the IDF." INN, June 14. Retrieved August 5, 2008, from http://www.inn.co.il/Articles/Article.aspx/4453

Levy, Daniel and Natan Sznaider. 2004. "The Institutionalization of Cosmopolitan Morality: The Holocaust and Human Rights." Journal of Human Rights 3: 143-57.

Lincoln, Yvonna S. and Egon G. Guba. 1985. Naturalistic Inquiry. Beverly Hills, CA: Sage.

Lio, Shoon, Scott Melzer, and Ellen Reese. 2006. "Constructing Fear and Appropriating 'Civil Rights': Rhetorical Strategies of Gun Rights and English Only Leaders." Paper presented at the Annual Meeting of the American Sociological Association in Montreal, Canada, August 2006. 
Lustick, Ian. 1988. For the Land and the Lord: Jewish Fundamentalism in Israel. New York: Council on Foreign Relations.

Lutz, Ellen L. and Kathryn Sikkink. 2000. "International Human Rights Law and Practice in Latin America." International Organization 54: 633-59.

Luz, Edud. 2002. "Jewish Ethics' as an Argument in the Public Debate over the Israeli Reaction to Palestinian Terror." Israel Studies 7: 134-56.

Matas, David. 2005. Aftershock: Anti-Zionism and Anti-Semitism. Toronto, Canada: Dundurn Press.

Maykut, Pamela and Richard Morehouse. 1994. Beginning Qualitative Research: A Philosophic and Practical Guide. London: The Falmer Press.

Meyer, John W., John Boli, George M. Thomas, and Francisco O. Ramirez. 1997. "World Society and the Nation-State." American Journal of Sociology 103: 144-81.

Meyer, John W., Joanne Nagel, and Conrad W. Snyder. 1993. “The Expansion of Mass Education in Botswana: Local and World Society Perspectives." Comparative Education Review 37: 454-75.

Meyer, John W. and Brian Rowan. 1977. "Institutionalized Organizations: Formal Structures as Myth and Ceremony." American Journal of Sociology 83: 340-63.

Misgav, Haim. 2005. "The Temporality of the Supreme Court." INN, June 13. Retrieved August 5, 2008, from http:/ /www.inn.co.il/Articles/Article.aspx/4450

Mudde, Cas and Joop Van Holsteyn. 2000. "The Netherlands: Explaining the Limited Success of the Extreme Right." Pp. 144-71 in The Politics of the Extreme Right: From the Margins to the Mainstream, edited by P. Hainsworth. London and New York: Pinter.

Pedatzur, Reuven. 1996. The Triumph of Embroilment: The Policy of the Eshkol Government in the Occupied Territories Following the Six Days War. Tel-Aviv: Bitan (Hebrew).

Risse, Thomas, Stephen C. Ropp, and Kathryn Sikkink, eds. 1999. The Power of Human Rights: International Norms and Domestic Change. Cambridge, UK: Cambridge University Press.

Samuels, Shimon. 2000. "Applying the Lessons of the Holocaust." Pp. 209-20 in Is the Holocaust Unique? edited by A. S. Rosenbaum. Boulder, CO: Westview.

Schofer, Evan and John W. Meyer. 2005. "The Worldwide Expansion of Higher Education in the Twentieth Century." American Sociological Review 70: 898-920.

Shor, Eran. 2008. "Conflict, Terrorism, and the Socialization of Human Rights Norms: The Spiral Model Revisited." Social Problems 55: 117-38.

Sprinzak, Ehud. 1991. The Ascendance of Israeli's Radical Right. Oxford, UK: Oxford University Press.

- 1998. "Extremism and Violence in Israel: The Crisis of Messianic Politics." Annals of the American Academy of Political and Social Science 555: 114-26.

-1999. Brother against Brother: Violence and Extremism in Israeli Politics from Altalena to the Rabin Assassination. New York: The Free Press.

Svasand, Lars. 1998. "Scandinavian Right-Wing Radicalism." Pp. 77-93 in The New Politics of the Right: Neo-Populist Parties and Movements in Established Democracies, edited by H.- G. Betz and S. Immerfall. New York: St. Martin's Press.

Truan, Yehuda. 2005. "Examination of Historical Parallels to the Disengagement Plan." Israeli Parliament- the Center for Research and Knowledge. Retrieved July 8, 2005, from http://www.knesset.gov.il/mmm/data/docs/m01039.doc (Hebrew)

Tzoref, Yehuda. 2005a. "Dissention Versus Submission." INN, January 9. Retrieved August 5, 2008, from http: / / www.inn.co.il/Articles/Article.aspx/3794

- 2005b. "Gush Shalom Talks about Peace." INN, January 31. Retrieved August 5, 2008, from http://www.inn.co.il/Articles/Article.aspx/3893 
2005c. "Renouncement of Citizenship." INN, March 5. Retrieved August 5, 2008, from http:/ / www.inn.co.il/Articles / Article.aspx/4034

Wolfsfeld, Gadi. 1984. "Collective Political Action and Media Strategy: The Case of Yamit." Journal of Conflict Resolution 28: 363-81.

Zertal, Idith and Akiva Eldar. 2004. Lords of the Land: The Settlers and the Israeli State 19672004. Or Yehuda, Israel: Kinneret, Zmora-Bitan, Dvir (Hebrew).

Ziv, Neta and Ronen Shamir. 2000. "Politics and Sub Politics in the Struggle against Land Discrimination." Theory and Critique 16: 45-66 (Hebrew). 